\title{
The Effect of Traditional Media Communication and Social Media Communication in Generating Consumer Based Brand Equity in Context of Pakistan
}

\author{
Muhammad Ali * $\quad$ Khalid M. Iraqi ${ }^{\dagger} \quad$ Lubna Khan ${ }^{\ddagger} \quad$ Faiza Salam ${ }^{\S}$
}

\begin{abstract}
The purpose of this study is to examine the impact of traditional media communication and social media communication in generating the consumer based brand equity. This study provides an important theoretical contribution by introducing prosumers and lead users as for user generated content in the conceptual model. The study has used conventional advertising for measuring traditional media communication whereas, firm and user generated content on social media were used to measure social media communication. The study has employed PLS-SEM to obtain the empirical results. The empirical findings suggested that traditional media communication and social media communication are equally important for creating brand equity. It was also concluded that firm created content has a stronger impact on brand awareness and functional brand image. As far as the user generated content is concerned, the study proposed that Prosumers have a stronger impact on functional brand image while lead users have a significant impact on hedonic brand image.
\end{abstract}

Keywords: Management support, work discretion, entrepreneurial education, previous entrepreneurial experience, time availability, entrepreneurship passion for inventing.

\section{Introduction}

Branding is a common practice followed by the producers since medieval times. Trademarking of the products protect the producers and buyers from low quality imitations. Now a days, brands have become more powerful marketing tools (Hakala, Svensson, \& Vincze, 2012). They are a representation of value for customers as well as firms. A brand signals a certain level of quality so that the customers who are satisfied by the product may choose that product again. From Aaker and Equity (1991)'s customer based brand equity dimensions, awareness is top of the list. If customer has no information about the brand, it will have no value or equity (Shimp, 2010).

Advertisement is, and always, have been the key variable that was used to influence the buying decisions of consumers. However, with time the consumers have become much

\footnotetext{
* Department of Management Sciences, IQRA University, Karachi, Pakistan.

${ }^{\dagger}$ Department of Public Administration, University of Karachi, Karachi, Pakistan.

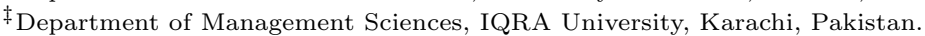

$\S$ Department of Management Sciences, IQRA University, Karachi, Pakistan.
} 
more intelligent in their decision making while buying a product (Shao, Grace, \& Ross, 2015). With rapid technological advancement, the concept of advertisement has changed. With the emergence of digital and social media marketing, consumers are becoming aware of the brands in more depth. In the recent times, where the technology is growing at an unprecedented rate, social media platforms have become an imperative part of global marketing communications. It has taken a large share in the advertisement budgets especially to reach the young generation. The value of advertisement on the social media forums such as, FaceBook, Instagram, YouTube, Twitter etc. is of great interest for marketers, managers and firms (Saxena \& Khanna, 2013).

However, traditional marketing tactics have not become obsolete. The reason could be that the tools used in the traditional marketing have got greater trust element than the social media marketing. This lack of confidence leads the marketers to use both tools simultaneously. According to Stephen and Galak (2012) traditional media outlets such as television, newspapers, magazines reach to greater segment of the society than the social media. On the same line, Pauwel et. al., (2010) also argued that traditional marketing tools hit the hidden interests of the consumers and makes them to search about the product online. Sundar, Narayan, Obregon, and Uppal (1998) postulated that traditional tools of advertisements like Television commercials, newspapers, magazines etc. have great impact on online sales. Advertising through conventional means compels the marketer to give a clear and catchy message through TVCs, whereas, social media advertising deliver a rich and deeper content and it is less costly than the traditional means (Huhman \& Limbu, 2016).

Previously, the procedure of attracting consumers was not such complex because one way communication existed between consumers and producers. But, with the emergence of social web, this communication process has become two way where not only firms but consumers are also involved. Interestingly, firms have realized the significance of this evolving era and have started taking interest in online platforms. Social media has become an important medium for capturing the market share after the dominance of social web.

Past studies present diversifying view about the idea of advertising and creating consumer purchase intention through it. For instance, according to Bruhn, Schoenmueller, and Schäfer (2012), conventional advertising creates greater brand awareness and purchase intention whereas, social media marketing has more influence on brand image and brand attitude. Olbrich and D. Schultz (2014) have found that WOM (word of mouth) can be spread through print media in more effective way. It also increases the brand appeal for potential buyers. However Neti, (2011) strongly emphasized the importance of social media and found that small firms allocate 6 percent of their advertising budget to social media marketing and it can grow up to 18 percent in the next few years. Schivinski and Dabrowski (2016) confirmed that social media user generated content contribute towards brand attitude and purchase intention positively.

Formerly, numerous studies have been conducted to discover the effects of traditional marketing strategies and social media marketing on the customer purchase intention. However, there is a strong need of exploring the impact of the combination of both marketing tools on the customer purchase intention (Stephen \& Galak, 2012; Castronovo \& Huang, 2012) and to know the impact of users' generated content on the purchase intention 
(Schivinski \& Dabrowski, 2016).

In the light of short literature review sketched above, the present study aims to analyse the impact of traditional and social media marketing by identifying the determinants of customer purchase intention. The study will also explore the effects of typologies of internet users such as prosumers (Toffler, 1980) and lead users (Von Hippel, 1986) in generating content by the users or buyers on social media. The study focuses on exploring that which of two mediums of advertising is more important to bring the customers on board. The findings can be helpful for the organization in setting up a plan of action and making strategies for capturing a larger market share and to utilize the user generated content.

The remaining part of the study is organized as follows. The second part deals with the review of the previous literature on the considerate issue. The review of the related literature is followed by the methodology of the study. The next part deals with empirical results and findings of the study. The study is then concluded with conclusion and suitable policy implications.

\section{Theoretical Background}

Schema Theory: To determine the consumer perspective about brand purchase intention, the present study employs 'Schema Theory'. This theory was presented by Piaget (2002). According to the given theory, Knowledge is stored in the form of small units known as Schemeta. These schema are used to for both understanding and reacting in situations where set of linked mental demonstrations are framed. Later, Bartlett, Bartlett, and Kintsch (1995) also used this theory to explain that the fact that new knowledge is influenced from the existing information. He also stated that schema are cognitive structure which stores knowledge in our memory and then let the individual use it when required.

A number of past studies have used Schema Theory in marketing context. For instance, Schema Theory is used in order to improve the concept of classical 4Ps. Similarly, Sujan and Bettman (1989) related Schema Theory in their study in order to determine that how consumer's brand and category perception is influenced by the brand positioning. In the same vein, (Hunt, 1971), while explaining the significance of marketing, used Schema theory and proposed that 'A theoretical schema is a systematically related set of statements, including some law like generalizations, that is empirically testable'. Bruhn et al. (2012) also used schema theory in their study for examining that how brand equity is affected by traditional and social media. Choi and Rifon (2002) used Schema theory in order to determine consumer response towards online purchase intention through social web advertising credibility. They suggested that Schema theory is most relevant to examine consumer mindset.

Based on this theory, following conceptual model is proposed: 
Figure 1

Conceptual Model

Communication Source

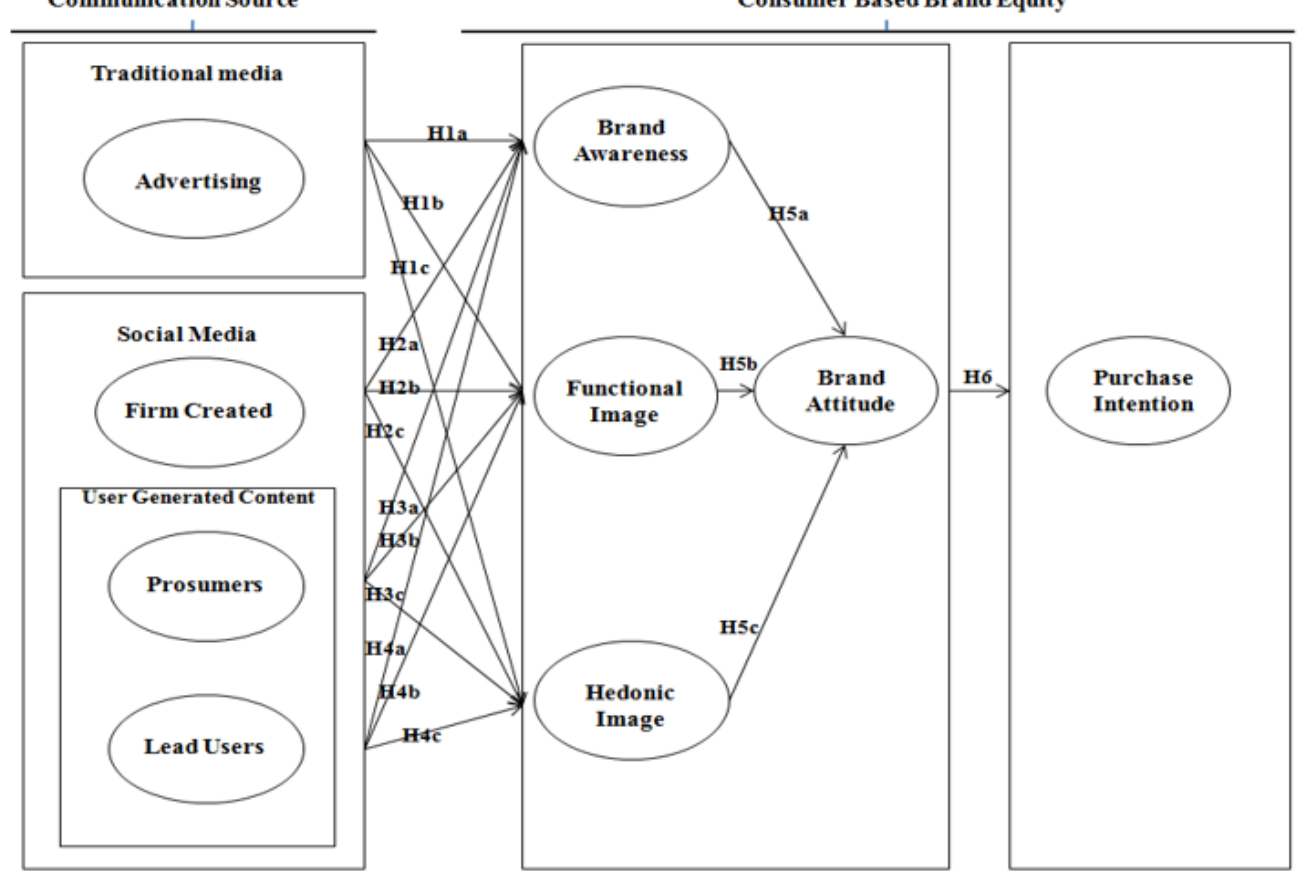

\section{Empirical Reviews}

\section{Traditional Advertising}

Munnukka, Uusitalo, and Toivonen (2016) explored the formation of peer-endorser credibility and its effects on formation of attitude. The authors found that peer endorser credibility is formed from trustworthiness, expertise, similarity and attractiveness dimensions that positively affects the attitude of the consumer towards the brands. The authors also claimed that product involvement also influences the advertising effectiveness. In the same vein, Modig and Rosengren (2014) examined the effects of advertisement creativity in retail background. The study found that retailers tend to invest on advertisement creativity because the creativity intensity establishes positive perceived product quality which persuades and leads to brand attitude and purchase intention. Results also showed that advertisement creativity positively affects the product perceived quality and enhances product value. Giakoumaki, Avlonitis, and Baltas (2016) explored the effect of ingredient advertising on purchase intention. The study found that if the host brand incorporates the advertised ingredients in the product, it positively affects the attitude and purchase intention towards the brand. 


\section{Social Media Advertising}

Olbrich and D. Schultz (2014) tried to investigate if print advertisement have any effect on the search engine advertisement. The study found out that advertisement budget and the extent of keyword matching affects the number of signed contracts. However, the clickthrough rate and the bid amount have a lesser influence on financial target variance. The study found a mediating effect of print advertisement on the number of conversions induced directly by search engine advertising. Habibi, Hamilton, Valos, and Callaghan (2015) investigated the electronic marketing orientation potential of an organization in order to evaluate the problems in business to business (B2B) social media implementation. The authors analysed four components of electronic marketing orientation namely, Philosophical component, Initiation component, Implementation Component and adoption component. The authors found that digital and social media marketing has significantly changed the mode advertising in terms of B2B marketing. In the same vein, Boateng and Okoe (2015) analysed the association between consumer's attitude towards social media advertising and their behavioural response and the moderating effect of corporate reputation in this relationship. The study found that a significant relationship occurs between consumer's attitude towards social media marketing and their behavioral responses. It was also found that corporate reputation moderates the relationship between consumer's attitude towards social media marketing and their behavioral responses. Similarly, Tsimonis and Dimitriadis (2014) examined why firms create web pages of their brands on social media, how are they using them and what policies are they employing. They study found that with the use social media pages, firm basically aim at interacting with their customers, announcing new products, providing new information and handling customer care services. With the use of social media pages, the firms want to increase their popularity, create brand awareness and customer engagement.

\section{Brand Awareness}

Sasmita and Mohd Suki (2015) explored the relationship among brand association, brand awareness, brand image, brand loyalty and brand equity for young consumers. The empirical findings suggested that young consumers get their insights about the products or brands from the social media. They can clearly recognize the product and their characteristics in comparison to other products from social media.

Hakala et al. (2012) examined the dimensions of consumer based brand equity and recall level of brand awareness. The study revealed that the dimensions of brand equity change with the changing cultural context. Also, the top-of-mind awareness, i.e., TOMA also changes with differing cultural context. Walsh, Rhenwrick, Williams, and Waldburger (2014) discussed two different strategies namely, brand extension and brand licensing for examining brand awareness. Various past researches have shown that brand awareness is how a consumer recalls a brand in his mind that leads him to make a purchase decision. According to the authors, extension and licensing are two different branding strategies and both of these strategies can have negative and positive impact on team's brands. The findings suggested that consumers can not successfully recognize the licensed products however they can identify team brand extensions. 


\section{Brand Image}

Vinhas Da Silva and Faridah Syed Alwi (2008) analysed the brand features that helps in creating positive brand image in online setting. The study found that for online etailers, features such as security, personalization, customer care and ease of use are vital components for determining corporate brand image. In the same context, Cho and Fiore (2015) have identified brand image, consumer's perception and feelings towards a brand as an important aspect because these characteristics determine the consumer's brand and product choices. An interesting finding was presented by Lee, Lee, and Wu (2011) who examined the variance of brand image after merger and acquisition especially when the acquirer has a weaker brand image and the acquired has a stronger one. The results presented that as the perceived differences between the the acquirer and acquired brands increase, the brand equity of acquirer also increases. Hu, Liu, Wang, and Yang (2012) examined the role of functional and symbolic image congruity in making up- consumer preferences. The results revealed that symbolic image congruity has a negative influence on consumers' brand preference when the perceived symbolic image of brand is higher than the ideal expectations of consumers.

\section{Brand Attitude}

Kachersky and Carnevale (2015) examined the effectiveness of using second person pronoun and first person pronoun with a brand name. The study also intended to examine the brand attitude that is created with usage of these pronouns. The findings showed that second person pronouns as 'You' evokes more favourable brand attitude than using a first person pronoun like ' $\mathrm{I}$ ' when the brand is positioned for social benefits. However, opposite case is true when the brand is positioned for personal benefits. Similarly, Pagla and Brennan (2014) evaluated the factors that can affect brand attitude development and brand behaviour among young consumers. The study concluded that children's brand attitude is primarily influenced by their elder siblings, parents and peers. Age was also found to have a significant influence on the brand buying decisions, where older children are more likely to buy brands than the younger ones. Liu, Li, Mizerski, and Soh (2012) also analysed the effects of the brand's personality congruity (BPC), the brand's user imagery congruity and the brand's usage imagery congruity in building up consumer's attitude and brand loyalty for luxury brands. The study findings suggested that symbolic benefits are the prime motivations behind luxury brand purchases. They are the non-product attributes like imagery. These symbolic benefits significantly help in creating brand loyalty and brand attitude.

In the similar context, Wu and Wang (2011) examined the use of electronic word of mouth in influencing the message source credibility on brand attitude. The empirical results indicated that positive eWOM message with higher message source credibility gives a better brand attitude than the eWOM message with lower source credibility. 


\section{Purchase Intention}

Duffett (2015) investigated the effect of facebook on the behavioural attitudes of millenials and tried to figure out if usage and demographic variables have any influence on purchase intentions and purchase perceptions. The empirical results confirmed that facebook advertisement has a positive influence on the purchase intention of millenials. The study also found that the signing in duration, usage and profile updation also facilitate these behavioural intentions. Huang (2012) also examined the influence of social and interactive features on users' online experiences and purchase intention of virtual goods. The findings of the study suggested that environmental features should be introduced and involved in order to improve users' online experiences and purchase intentions. Weisberg, Te'eni, and Arman (2011) postulated that internet buying has got unique features that make it different from the conventional shopping process, specifically when it comes to social context. The study tried to investigate the relationship between internet purchases made in the past and the purchase intention. The results clearly stated that online past purchase experiences do predict the purchase intention.

\section{Typology of Internet Users}

\section{Prosumers}

The prosumer are highly significant type of users and they can be regarded as productive labors who generate surplus value (Ziemba \& Eisenbardt, 2014; Fuchs, 2012; Ritzer \& Jurgenson, 2010). According to past studies, prosumers are very important and firms should involve them in inventive activities. In fact, prosumers are involved by the organization in co creation, innovation and expedition of information and knowledge (Boni, 2011).

Ziemba and Eisenbardt (2014) examined that how young prosumers are aware of brand by using ICT's information and communication technologies. Prosumers are unpaid or third party advertisers for the companies who are involved in generating content about brand on SNS. Empirical results showed that prosumers are highly involved in activities and supports with their creativity and intelligence.

\section{Lead Users}

The later type of users also have significance for spreading and creating knowledge (Von Hippel, 1986). Lead users are very important as they help in (i) idea generation (ii) trend research (iii) generating connections (iv) idea improvement (Lilien, Morrison, Searls, Sonnack, \& Hippel, 2002).

Kratzer and Lettl (2009) highlighted the distinctive roles of lead users and opinion leader in the social network of school children. However, lead users and opinion leaders are known for the same purpose as both are the drivers of innovation. The study showed that positioning of lead users and opinion leaders is similar. With empirical analysis, it was concluded that lead users are positioned as boundary spanners as they spread knowledge to various group of people. 


\section{Measurement Instrument}

The study has used eight constructs namely, traditional media advertisement, firm created and user created content on social media, brand awareness, brand image, brand attitude, prosumers, lead users and purchase intention. The constructs items were taken from past empirical researches. The face and content validity of the instrument was ensured from the market and academic experts. The items for traditional media advertisement, firm generated and user generate content of social media were taken from Mägi (2003); Tsiros, Mittal, and Ross Jr (2004). The items of brand attitude were taken from Yoo, Donthu, and Lee (2000). Items of brand image (functional and hedonic) were adopted from Scott and English (1989); Verhoef, Langerak, and Donkers (2007). For brand attitude, items were taken from Abzari, Ghassemi, and Vosta (2014) and (Villarejo-Ramos \& SanchezFranco, 2005). The items of purchase intention were taken from Grewal, Krishnan, Baker, and Borin (1998). All items were developed in the form of statement. We used 5-point likert scaling ranging from strongly disagree $=1$ to strongly agree $=5$ for every item. We also included demographic factors in the questionnaire to have further information about the respondent's profile. In order to examine the validity and reliability of the survey instrument, a pilot study was also done before the actual survey was conducted. The survey questionnaire was distributed among the university faculty members who had their expertise in research methodology. The results of pilot study revealed that the items of every construct used in the questionnaire are relevant and understandable in the context of the present study.

\section{Data Collection Procedure}

The present study has used questionnaire based survey method for data collection. To conduct the present study, we have targeted those consumers who are active internet users and spend some time on social media websites for instance Facebook, Twitter, LinkedIn etc. responses were collected from both males and females. The study is conducted in Karachi because Karachi is the biggest city of Pakistan and its population is very much diverse. Almost all income classes are found in Karachi who are actively using internet and social media for their purchases. The sampling technique used for the collection of data was Convenience Sampling. Convenience sampling because researcher faced limitations in terms of finances and time for collecting data. In addition, A study reported that a sample taken from random sampling may fail to be a true representative of the population whereas, according to Kothari (2004), with convenience sampling purposeful selection of respondents can be done.

To identify the sample size, we followed the guidelines provided by Comrey and Lee (1992). According to Comrey and Lee (1992); Ali, Raza, Qazi, and Puah (2018); Ali, Raza, and Puah (2017), a sample of 1000 is regarded as excellent, 500 as very good, 300 as good and 50 as poor. For the present study we collected a sample of 325 respondent. Out of those 325, 293 were useable hence used for empirical analysis. Moreover, we also assured that the respondents are treated as politely and were requested to participate in the research voluntarily. It was also ensured that the personal information of the respondents should not be leaked or misused. 


\section{Results and Discussion}

\section{Descriptive Statistics}

The description of the respondents are illustrated below in table 1 . In this study, the participation of male is higher than female i.e. male are $76 \%$ whereas only $23.9 \%$ female participated. In addition, majority of the respondents are lying within the age group between 21 years to 25 years, $36 \%$ respondents have age between 26 years to 30 years, $10 \%$ respondents are above 30 years and $4.4 \%$ respondents are below 20 years age. Moreover, the educational level of most of the respondents are graduate i.e. $71 \%$, respondents having post graduate are $26 \%$ and the least respondents approximately $2 \%$ are undergraduate students. Most of the respondents earn 50,000 to 80,000, 17\% respondents earn 30,000 to $50,000,10 \%$ respondents earn 15000 to 30,000 and only $1 \%$ respondents earn below 15,000 . Almost 50\% respondents often use social media, $17 \%$ incidentally use and $16 \%$ respondents avoid social media usage.

Table 1

Descriptive Statistics of the Respondents

\begin{tabular}{|c|c|c|}
\hline Demographics & Frequency & Percent \\
\hline \multicolumn{3}{|l|}{ Gender } \\
\hline Male & 223 & 76.1 \\
\hline Female & 70 & 23.9 \\
\hline Total & 293 & 100 \\
\hline \multicolumn{3}{|l|}{ Age } \\
\hline 18 Years-20 Years & 13 & 4.4 \\
\hline 21 Years-25 Years & 144 & 49.1 \\
\hline 26 Years-30 Years & 106 & 36.2 \\
\hline Above 30 Years & 30 & 10.2 \\
\hline Total & 293 & 100 \\
\hline \multicolumn{3}{|l|}{ Education } \\
\hline Undergraduate & 8 & 2.7 \\
\hline Graduate & 208 & 71 \\
\hline Postgraduate & 77 & 26.3 \\
\hline Total & 293 & 100 \\
\hline \multicolumn{3}{|l|}{ Income level } \\
\hline $10,000-15,000$ & 5 & 1.7 \\
\hline $15,001-30,000$ & 30 & 10.2 \\
\hline $30,001-50,000$ & 51 & 17.4 \\
\hline $50,001-80,000$ & 179 & 61.1 \\
\hline 80,001 or more & 28 & 100 \\
\hline Total & 293 & 100 \\
\hline \multicolumn{3}{|l|}{ Social Media Usage } \\
\hline Often & 145 & 49.5 \\
\hline Incidentally & 50 & 17.1 \\
\hline Very Less & 49 & 16.7 \\
\hline Not at all & 49 & 16.7 \\
\hline Total & 293 & 100 \\
\hline
\end{tabular}




\section{Measurement Model}

Before estimating a structural model, we have ensured the construct validity and reliability of the model by employing convergent validity, content validity and discriminant validity. Engellant, Holland, and Piper (2016) stated that convergent validity checks whether the set of items of a latent variables have high variances or not. In the current study, we checked the convergent validity of the model by verifying the factor loadings, average variance extracted (AVE) and composite reliability. Table 2 given below displays the statistics of AVE and composite reliability. The statistics of CR and AVE confirms the convergent validity of the model, as all the values of composite reliability are greater than 0.7, which meets the required criteria. Moreover, according to Fornell and Larcker (1981), the convergent validity of a model is considered adequate, if the value of average variance extracted (AVE) is above 0.5 .

Table 2

Reliability and Validity

\begin{tabular}{lcc}
\hline Constructs & CR & AVE \\
\hline BA & 0.849 & 0.586 \\
BAT & 0.808 & 0.584 \\
FBI & 0.851 & 0.657 \\
FCS & 0.839 & 0.635 \\
HBI & 0.867 & 0.566 \\
LU & 0.877 & 0.781 \\
PI & 0.853 & 0.593 \\
PRO & 0.848 & 0.584 \\
TMC & 0.773 & 0.633 \\
\hline \multicolumn{2}{l}{ Source: Authors' Estimation }
\end{tabular}

The content validity of the model is checked by using confirmatory factor analysis. The results are displayed in table 3, which shows the cross loadings of each construct. Hair, Ringle, and Sarstedt (2013) defines the criteria of content validity that if cross loadings is 0.7 or above it confirms the content validity and also indicates the high correlation between all the measured variables of a construct. In our case, all the factor loadings are above 0.7, hence confirms the content validity.

The degree to which an items of a variable distinguish from the other variable items is known as discriminant validity (Engellant et al., 2016). We have used different approaches to check the discriminant validity of the measurement model. By using (Fornell \& Larcker, 1981), we have checked the discriminant validity. Gefen and Straub (2005) propose that all the items of a variable should strongly loaded with their construct and weakly loaded with the other construct, but the value should be greater than 0.1 . Table 4 displays the matrix that shows the model has the discriminant validity because all the diagonal values have greater values than the others and the columns and rows values are also greater than 0.1. The diagonal values in the correlation matrix indicates the square root of the average variance extracted (AVE). 
Table 3

Cross Loadings

\begin{tabular}{|c|c|c|c|c|c|c|c|c|c|}
\hline Constructs & BA & BAT & FBI & FCS & HBI & $\mathbf{L U}$ & PI & PRO & TMC \\
\hline $\mathrm{BA} 3$ & 0.812 & & & & & & & & \\
\hline BA4 & 0.779 & & & & & & & & \\
\hline BA5 & 0.845 & & & & & & & & \\
\hline BA6 & 0.807 & & & & & & & & \\
\hline BAT3 & & 0.774 & & & & & & & \\
\hline BAT4 & & 0.874 & & & & & & & \\
\hline BAT5 & & 0.745 & & & & & & & \\
\hline FBI3 & & & 0.727 & & & & & & \\
\hline FBI4 & & & 0.795 & & & & & & \\
\hline FBI5 & & & 0.813 & & & & & & \\
\hline FCS1 & & & & 0.793 & & & & & \\
\hline FCS2 & & & & 0.775 & & & & & \\
\hline FCS3 & & & & 0.767 & & & & & \\
\hline HBI1 & & & & & 0.782 & & & & \\
\hline HBI2 & & & & & 0.833 & & & & \\
\hline HBI3 & & & & & 0.789 & & & & \\
\hline HBI4 & & & & & 0.756 & & & & \\
\hline HBI5 & & & & & 0.805 & & & & \\
\hline LU1 & & & & & & 0.897 & & & \\
\hline LU2 & & & & & & 0.870 & & & \\
\hline PI1 & & & & & & & 0.819 & & \\
\hline $\mathrm{PI} 2$ & & & & & & & 0.855 & & \\
\hline PI3 & & & & & & & 0.820 & & \\
\hline PI4 & & & & & & & 0.711 & & \\
\hline PRO2 & & & & & & & & 0.761 & \\
\hline PRO3 & & & & & & & & 0.829 & \\
\hline PRO4 & & & & & & & & 0.777 & \\
\hline PRO5 & & & & & & & & 0.784 & \\
\hline TMC3 & & & & & & & & & 0.855 \\
\hline TMC4 & & & & & & & & & 0.884 \\
\hline
\end{tabular}

Source: Authors' Estimation

Table 4

Fornell \& Larker (1981) Criteria

\begin{tabular}{lccccccccc}
\hline Constructs & BA & BAT & FBI & FCS & HBI & LU & PI & PRO & TMC \\
\hline BA & 0.765 & & & & & & & & \\
BAT & 0.306 & 0.764 & & & & & & & \\
FBI & 0.382 & 0.473 & 0.810 & & & & & & \\
FCS & 0.353 & 0.254 & 0.386 & 0.797 & & & & & \\
HBI & 0.469 & 0.520 & 0.658 & 0.508 & 0.752 & & & & \\
LU & 0.216 & 0.219 & 0.362 & 0.35 & 0.419 & 0.884 & & & \\
PI & 0.306 & 0.458 & 0.439 & 0.273 & 0.467 & 0.383 & 0.770 & & \\
PRO & 0.305 & 0.246 & 0.423 & 0.469 & 0.439 & 0.426 & 0.347 & 0.764 & \\
TMC & 0.133 & 0.090 & 0.300 & 0.306 & 0.231 & 0.276 & 0.173 & 0.202 & 0.796 \\
\hline
\end{tabular}

Source: Authors' Estimation

We have also used Heterotrait-Monotrait ratio (HTMT) approach to test the discrimi- 
nant validity of the model. Hair et al. (2013) define the criteria that ensures the discriminant validity, if the values in the correlation matrix is below 0.85 than it confirms the discriminant validity of the model. Table 5 reports the results of HTMT, it is showed all the values in the matrix are less than 0.85 , thus confirms the discriminant validity of the measurement model.

Table 5

Heterotrait- Monotrait Ratio (HTMT)

\begin{tabular}{llllllllll}
\hline Constructs & BA & BAT & FBI & FCS & HBI & LU & PI & PRO & TMC \\
\hline BA & & & & & & & & & \\
BAT & 0.415 & & & & & & & & \\
FBI & 0.512 & 0.676 & & & & & & & \\
FCS & 0.452 & 0.356 & 0.508 & & & & & & \\
HBI & 0.596 & 0.716 & 0.846 & 0.649 & & & & & \\
LU & 0.248 & 0.263 & 0.414 & 0.399 & 0.463 & & & & \\
PI & 0.393 & 0.629 & 0.577 & 0.374 & 0.600 & 0.442 & & & \\
PRO & 0.403 & 0.345 & 0.547 & 0.623 & 0.550 & 0.489 & 0.460 & & \\
TMC & 0.212 & 0.174 & 0.504 & 0.576 & 0.394 & 0.438 & 0.314 & 0.364 & \\
\hline Source: Authors' Estimation & & & & & & &
\end{tabular}

\section{Structural Model and Hypothesis Testing}

Once the measurement model validated, we test the hypothesis using structural equation modeling in smart PLS 3.2.3 version. PLS analysis use bootstrapping technique (Haenlein \& Kaplan, 2004; Tsimonis \& Dimitriadis, 2014). We utilized formative measurement to estimate a structural model. First, we checked the predictive power and predictive relevance of the dependent variable in the proposed model using R-square and Q-square. Hair et al. (2013) proposed a criteria for predict power of the construct, if the R-square value is 0.75 it considers substantial, 0.5 is moderate and 0.25 value indicates weak power. Table 6 presents the values of R-square, which indicates that the brand attitude (0.303), functional brand image (0.272) and hedonic brand image (0.349) moderately predicted by the set of predictors. However, brand awareness (0.152) and purchase intention (0.209) weakly predicted by the predictors. On the other hand, table 6 also displays the values of Q-square. As Hair et al. (2013) proposed a criteria that if the value is greater than zero it confirms the predictive relevancy. In this case, the Q-square value of all the constructs is greater than zero except brand awareness (0.076), which confirms the predictive relevancy of the constructs.

Table 6

\begin{tabular}{lcc}
\multicolumn{3}{l}{ Results for Correlation Analysis } \\
\hline Constructs & R-square & $Q^{2}$ \\
\hline BA & 0.152 & 0.076 \\
BAT & 0.303 & 0.158 \\
FBI & 0.272 & 0.161 \\
HBI & 0.349 & 0.182 \\
PI & 0.209 & 0.117 \\
\hline \multicolumn{3}{l}{ Source: Authors' Estimation }
\end{tabular}


The result of hypothesis testing is shown in table 7 that reject the $\mathrm{H} 1$, traditional media insignificantly and positively influence brand awareness. However, the traditional media has a significant and positive impact on the functional brand image, this finding is similar to Bruhn et al. (2012). Contrary to that, traditional media has insignificantly related to hedonic brand image and hence this finding reject the H3. Furthermore, firm created social media has a positive and significant relationship with brand awareness, functional brand image and hedonic brand image, thus accept H4, H5 and H6. These results are similar with the study of Bruhn et al. (2012), they have also found positive and significant relationship of firms created social media on brand awareness, hedonic brand image and functional brand image.

The variable prosumers is also found significant and positive with brand awareness, functional brand image and hedonic brand image. Hence the H7, H8 and H9 accepted, it is because prosumers are well-informed about the brand they use and exert to improve the design and other service of the product (Kozinets, 1999). Similarly, prosumers use different channels to improve the functional image of the product (Hoeffler \& Keller, 2002). Likewise, prosumers use unique content over internet or any other source to create and sustain a hedonic image of a brand. On the other hand, an insignificant but positive relationship found between lead users and brand awareness. It is because, the function of lead users are sometimes not a part of firms branding strategies (Wang, Hsiao, Yang, \& Hajli, 2016). In contrast, lead users have a significant and positive impact on both the functional brand image and the hedonic brand image. They create innovation and improve brand image.

Table 7

Hypothesis Testing Results

\begin{tabular}{cccccc}
\hline Hypothesis & Relationships & $\operatorname{Beta}(\beta)$ & T-Statistics & P-Values & Remarks \\
\hline H1 & TMC->BA & 0.007 & 0.431 & 0.939 & Not Supported \\
H2 & TMC->FBI & 0.156 & 1.937 & 0.053 & Supported \\
H3 & TMC->HBI & 0.032 & 0.076 & 0.667 & Not supported \\
H4 & FCS->BA & 0.256 & 2.648 & 0.008 & Supported \\
H5 & FCS->FBI & 0.169 & 1.817 & 0.069 & Supported \\
H6 & FCS->HBI & 0.337 & 3.520 & 0.000 & Supported \\
H7 & PRO->BA & 0.160 & 1.680 & 0.093 & Supported \\
H8 & PRO->FBI & 0.247 & 2.955 & 0.003 & Supported \\
H9 & PRO->HBI & 0.183 & 2.353 & 0.019 & Supported \\
H10 & LU->BA & 0.056 & 0.650 & 0.516 & Not supported \\
H11 & LU->FBI & 0.155 & 1.864 & 0.062 & Supported \\
H12 & LU->HBI & 0.214 & 2.887 & 0.004 & Supported \\
H13 & BA->BAT & 0.059 & 0.724 & 0.469 & Not supported \\
H14 & FBI->BAT & 0.223 & 2.471 & 0.016 & Supported \\
H15 & HBI->BAT & 0.345 & 3.615 & 0.000 & Supported \\
H16 & BAT->PI & 0.458 & 5.798 & 0.000 & Supported \\
\hline Source: Authors' Estimation & & & &
\end{tabular}

The null hypothesis H13 rejects because brand awareness found insignificant with brand attitude. The finding, stating that sometimes high level of brand awareness leads to negative promotions that subsequently unchanged the attitude of the customers. In addition, functional brand image and hedonic brand image positively and significantly influence brand attitude. These findings are similar to Bruhn et al. (2012). Finally, the last hypoth- 
esis H16 is also accepted because brand attitude and purchase intentions are positively and significantly related to each other and it is supported by Schivinski and Dabrowski (2016).

\section{Conclusion and Recommendations}

This study explores the effects of traditional media communication and social media communication in creating consumer based brand equity. To achieve the objective, we have used quantitative approach and the data was gathered from the respondents who are particularly from Karachi and are the users of social media and traditional media. A sample data of 293 respondents were collected using non-random (convenience) sampling technique. To process the data, we have employed several statistical techniques, such as structural equation modeling (SEM) using PLS. Prior to that, we have checked the proposed model fitness, content and convergent validity, reliability and discriminant validity using relevant statistical techniques like, confirmatory factor analysis, (Fornell \& Larcker, 1981) and HTMT criteria.

Once the validity and reliability of the model have ensured, we test the hypothesis by using structural equation modeling. Findings of our study suggest that traditional media communication has a direct effect on brand awareness, functional brand image and hedonic brand image. However, the effects of traditional media communication on brand awareness and hedonic brand image are found unimportant in Pakistani context. In addition, the impact of firm created social media found significantly positive on brand awareness, hedonic brand image and functional brand image. Similarly, prosumers have also directly and significantly related to brand awareness, hedonic brand image and functional brand image. Whereas, lead users insignificantly effect brand awareness but significantly influence both the brand image i.e. hedonic and functional. On the other hand, brand awareness has no impact on brand attitude but functional brand image and hedonic brand image have a significant and direct relationship. Finally, brand attitude has strongly influenced purchase intentions of the consumers.

Social media communication provides several opportunity to the companies to interact with the consumers and influence their attitude and purchase intention. It is highly recommended for the companies to engage with their consumers through social media and try to deem their perception about the products or services. It is one the best platforms that bring consumers together and provide opportunities to the like-minded consumers to talk about their brands. Companies should take social media as an important element in the marketing mix strategy so that it boosts brand equity. In future, the consumer usage of social media will increase brand equity and it also reduces cost of advertising.

Though the objective of the study is achieved, even than there are some limitations need to be highlighted for the future researchers. Since the study used advertising as a substitute variable for traditional media communication, future researchers can use some other variables like, celebrity endorsement and sponsoring to investigate the interplay of traditional media with social media communication. Secondly, researchers are encouraged to use large sample size other than Karachi. Additionally, researchers should also relate their companies social media communication with the financial performance which may 
lead to financial success of the firm.

\section{References}

Aaker, D. A., \& Equity, M. B. (1991). The free press. New York, 206.

Abzari, M., Ghassemi, R. A., \& Vosta, L. N. (2014). Analysing the effect of social media on brand attitude and purchase intention: The case of Iran Khodro company. ProcediaSocial and Behavioral Sciences, 143, 822-826.

Ali, M., Raza, S. A., \& Puah, C.-H. (2017). Factors affecting to select islamic credit cards in Pakistan: The TRA model. Journal of Islamic Marketing, 8(3), 330-344.

Ali, M., Raza, S. A., Qazi, W., \& Puah, C.-H. (2018). Assessing e-learning system in higher education institutes: Evidence from structural equation modelling. Interactive Technology and Smart Education, 15(1), 59-78.

Bartlett, F. C., Bartlett, F. C., \& Kintsch, W. (1995). Remembering: A study in experimental and social psychology. Cambridge University Press.

Boateng, H., \& Okoe, A. F. (2015). Consumers' attitude towards social media advertising and their behavioural response: The moderating role of corporate reputation. Journal of Research in Interactive Marketing, 9(4), 299-312.

Bruhn, M., Schoenmueller, V., \& Schäfer, D. B. (2012). Are social media replacing traditional media in terms of brand equity creation? Management Research Review, 35(9), 770-790.

Castronovo, C., \& Huang, L. (2012). Social media in an alternative marketing communication model. Journal of Marketing Development and Competitiveness, 6(1), 117-134.

Cho, E., \& Fiore, A. M. (2015). Conceptualization of a holistic brand image measure for fashion-related brands. Journal of Consumer Marketing, 32(4), 255-265.

Choi, S. M., \& Rifon, N. J. (2002). Antecedents and consequences of web advertising credibility: A study of consumer response to banner ads. Journal of Interactive Advertising, 3(1), 12-24.

Comrey, A., \& Lee, H. (1992). Interpretation and application of factor analytic results. Comrey AL, Lee HB. A first course in factor analysis, 2.

Duffett, R. G. (2015). Facebook advertising's influence on intention-to-purchase and purchase amongst millennials. Internet Research, 25(4), 498-526.

Engellant, K. A., Holland, D. D., \& Piper, R. T. (2016). Assessing convergent and discriminant validity of the motivation construct for the technology integration education (TIE) model. Journal of Higher Education Theory \& Practice, 16(1), 37-50.

Fornell, C., \& Larcker, D. F. (1981). Evaluating structural equation models with unobservable variables and measurement error. Journal of Marketing Research, 18(1), $39-50$.

Fuchs, C. (2012). The political economy of privacy on facebook. Television $\&$ New Media, 13(2), 139-159.

Gefen, D., \& Straub, D. (2005). A practical guide to factorial validity using PLS-Graph: Tutorial and annotated example. Communications of the Association for Information systems, 16(1), 91-109. 
Giakoumaki, C., Avlonitis, G. J., \& Baltas, G. (2016). Does ingredient advertising work? Some evidence on its impact. Journal of Business $\&$ Industrial Marketing, 31(7), 901-913.

Grewal, D., Krishnan, R., Baker, J., \& Borin, N. (1998). The effect of store name, brand name and price discounts on consumers' evaluations and purchase intentions. Journal of Retailing, 74 (3), 331-352.

Habibi, F., Hamilton, C. A., Valos, M. J., \& Callaghan, M. (2015). E-marketing orientation and social media implementation in B2B marketing. European Business Review, $27(6), 638-655$.

Haenlein, M., \& Kaplan, A. M. (2004). A beginner's guide to partial least squares analysis. Understanding Statistics, 3(4), 283-297.

Hair, J. F., Ringle, C. M., \& Sarstedt, M. (2013). Partial least squares structural equation modeling: Rigorous applications, better results and higher acceptance. Long Range Planning, 46(1-2), 1-12.

Hakala, U., Svensson, J., \& Vincze, Z. (2012). Consumer-based brand equity and top-ofmind awareness: A cross-country analysis. Journal of Product $\& 5$ Brand Management, 21(6), 439-451.

Hoeffler, S., \& Keller, K. L. (2002). Building brand equity through corporate societal marketing. Journal of Public Policy \& Marketing, 21(1), 78-89.

$\mathrm{Hu}$, J., Liu, X., Wang, S., \& Yang, Z. (2012). The role of brand image congruity in Chinese consumers' brand preference. Journal of Product \& Brand Management, 21(1), 26-34.

Huang, E. (2012). Online experiences and virtual goods purchase intention. Internet Research, 22(3), 252-274.

Hunt, S. D. (1971). The morphology of theory and the general theory of marketing. Journal of Marketing, 35(2), 65-68.

Kachersky, L., \& Carnevale, M. (2015). Effects of pronoun brand name perspective and positioning on brand attitude. Journal of Product \&5 Brand Management, 24(2), $157-164$.

Kothari, C. R. (2004). Research methodology: Methods and techniques. New Age International.

Kozinets, R. V. (1999). E-tribalized marketing?: The strategic implications of virtual communities of consumption. European Management Journal, 17(3), 252-264.

Kratzer, J., \& Lettl, C. (2009). Distinctive roles of lead users and opinion leaders in the social networks of schoolchildren. Journal of Consumer Research, 36 (4), 646-659.

Lee, H.-M., Lee, C.-C., \& Wu, C.-C. (2011). Brand image strategy affects brand equity after M\&A. European Journal of Marketing, 45(7/8), 1091-1111.

Lilien, G. L., Morrison, P. D., Searls, K., Sonnack, M., \& Hippel, E. v. (2002). Performance assessment of the lead user idea-generation process for new product development. Management Science, 48(8), 1042-1059.

Liu, F., Li, J., Mizerski, D., \& Soh, H. (2012). Self-congruity, brand attitude, and brand loyalty: A study on luxury brands. European Journal of Marketing, 46(7/8), 922937. 
Mägi, A. W. (2003). Share of wallet in retailing: The effects of customer satisfaction, loyalty cards and shopper characteristics. Journal of Retailing, 79(2), 97-106.

Modig, E., \& Rosengren, S. (2014). Can advertising creativity affect product perceptions and retailer evaluations? Journal of Product 8 Brand Management, 23(6), 452-461.

Munnukka, J., Uusitalo, O., \& Toivonen, H. (2016). Credibility of a peer endorser and advertising effectiveness. Journal of Consumer Marketing, 33(3), 182-192.

Olbrich, R., \& D. Schultz, C. (2014). Multichannel advertising: Does print advertising affect search engine advertising? European Journal of Marketing, 48(9/10), 17311756 .

Pagla, M., \& Brennan, R. (2014). The development of brand attitudes among young consumers. Marketing Intelligence \& Planning, 32(6), 687-705.

Piaget, J. (2002). The language and thought of the child. London: Routledge \& Paul.

Ritzer, G., \& Jurgenson, N. (2010). Production, consumption, prosumption: The nature of capitalism in the age of the digital 'prosumer'. Journal of Consumer Culture, 10(1), $13-36$.

Sasmita, J., \& Mohd Suki, N. (2015). Young consumers' insights on brand equity: Effects of brand association, brand loyalty, brand awareness, and brand image. International Journal of Retail \& Distribution Management, 43(3), 276-292.

Saxena, A., \& Khanna, U. (2013). Advertising on social network sites: A structural equation modelling approach. Vision, 17(1), 17-25.

Schivinski, B., \& Dabrowski, D. (2016). The effect of social media communication on consumer perceptions of brands. Journal of Marketing Communications, 22(2), 189214.

Scott, D., \& English, F. (1989). Tracking automotive intentions and imagery-a case-study. Journal of Advertising Research, 29(1), 13-20.

Shao, W., Grace, D., \& Ross, M. (2015). Self-regulatory focus and advertising effectiveness. Marketing Intelligence \& Planning, 33(4), 612-632.

Shimp, T. A. (2010). Integrated marketing communication in advertising and promotion, South-Western Cengage Learning Australia, South Melbourne.

Stephen, A. T., \& Galak, J. (2012). The effects of traditional and social earned media on sales: A study of a microlending marketplace. Journal of Marketing Research, 49(5), $624-639$.

Sujan, M., \& Bettman, J. R. (1989). The effects of brand positioning strategies on consumers' brand and category perceptions: Some insights from schema research. Journal of Marketing Research, 26(4), 454-467.

Sundar, S. S., Narayan, S., Obregon, R., \& Uppal, C. (1998). Does web advertising work? Memory for print vs. online media. Journalism \& Mass Communication Quarterly, $75(4), 822-835$.

Toffler, A. (1980). The third wave. New York: William Morrow and Company.

Tsimonis, G., \& Dimitriadis, S. (2014). Brand strategies in social media. Marketing Intelligence $\&$ Planning, 32(3), 328-344.

Tsiros, M., Mittal, V., \& Ross Jr, W. T. (2004). The role of attributions in customer satisfaction: A reexamination. Journal of Consumer Research, 31(2), 476-483. 
Verhoef, P. C., Langerak, F., \& Donkers, B. (2007). Understanding brand and dealer retention in the new car market: The moderating role of brand tier. Journal of Retailing, 83(1), 97-113.

Villarejo-Ramos, A. F., \& Sanchez-Franco, M. J. (2005). The impact of marketing communication and price promotion on brand equity. Journal of Brand Management, 12(6), 431-444.

Vinhas Da Silva, R., \& Faridah Syed Alwi, S. (2008). The link between offline brand attributes and corporate brand image in bookstores. Journal of Product $\&$ Brand Management, 17(3), 175-187.

Von Hippel, E. (1986). Lead users: a source of novel product concepts. Management Science, 32(7), 791-805.

Walsh, P., Rhenwrick, I., Williams, A., \& Waldburger, A. (2014). Team brand extension or licensed product? Examining consumer awareness of two distinct brand strategies. Sport, Business and Management: An International Journal, 4(2), 96-108.

Wang, Y., Hsiao, S.-H., Yang, Z., \& Hajli, N. (2016). The impact of sellers' social influence on the co-creation of innovation with customers and brand awareness in online communities. Industrial Marketing Management, 54, 56-70.

Weisberg, J., Te'eni, D., \& Arman, L. (2011). Past purchase and intention to purchase in e-commerce: The mediation of social presence and trust. Internet Research, 21(1), $82-96$.

Wu, P. C., \& Wang, Y.-C. (2011). The influences of electronic word-of-mouth message appeal and message source credibility on brand attitude. Asia Pacific Journal of Marketing and Logistics, 23(4), 448-472.

Yoo, B., Donthu, N., \& Lee, S. (2000). An examination of selected marketing mix elements and brand equity. Journal of the Academy of Marketing Science, 28(2), 195-211.

Ziemba, E., \& Eisenbardt, M. (2014). Prosumers' eagerness for knowledge sharing with enterprises-a polish study. Online Journal of Applied Knowledge Management, 2(1), $40-58$. 